\title{
CALCIUM/SODIUM EXCHANGE IN PURIFIED SECRETORY VESICLES FROM BOVINE NEUROHYPOPHYSES
}

Torben Særmark ${ }^{1}$ ), Niels A. Thorn ${ }^{1}$ ) and Manfred Gratzl ${ }^{2}$ )

1) Institute of Medical Physiology C, University of Copenhagen Blegdamsvej 3c, DK-2200 Copenhagen $N$, Denmark

2) Division of Clinical Morphology, University of U1m, D-79 Ulm, F.R.G.

\section{ABSTRACT}

Purified secretory vesicles isolated from bovine neurohypophyses take up $\mathrm{Na}^{+}$under the same circumstances where an efflux of $\mathrm{Ca}^{2}+$ takes place, suggesting a $\mathrm{Na}^{+} / \mathrm{Ca}^{2+}$ exchange. Potassium cannot substitute for $\mathrm{Na}^{+}$in this process. Also, a $\mathrm{Ca}^{2+} / \mathrm{Ca}^{2+}$ exchange can occur. Inhibiting the latter process by $\mathrm{Mg}^{2+}$ allowed to estimate an apparent $\mathrm{K}_{\mathrm{M}}$ of $0.7 \mu \mathrm{M}$ free $\mathrm{Ca}^{2+}$ and $\mathrm{a}$ maximal uptake of $1.5 \mathrm{nmol} \times \mathrm{mg}$ protein ${ }^{-1} \mathrm{xmin}^{-1} \mathrm{Ca}^{2+}$ in exchange for $\mathrm{Na}^{+}$.

The vesicles did not contain plasma membrane marker $\left(\mathrm{Na}^{+} / \mathrm{K}^{+}\right.$ ATPase) as shown by distribution analyses on the density gradients on which they were purified. Similarly, distribution studies also showed that no other ATPase activity could be detected in the purified vesicle fraction.

It is concluded that a $\mathrm{Na}^{+} / \mathrm{Ca}^{2}+$ exchange is operating across the secretory vesicle membrane and that it is not directly dependent on ATP hydrolysis.

\section{INTRODUCTION}

The existence in nerve terminals of non mitochondrial $\mathrm{Ca}^{2+}$ sequestering systems with high affinity has been proposed by several authors (1-5). The systems described up to now, e.g. in brain synaptosomes (3) and in the neurohypophysis (5) seem to be dependent on adenosine 5'-triphosphate (ATP).

The hormone-containing neurohypophyseal secretory vesicles within the terminals also contain $\mathrm{Ca}^{2+}$, as shown both by electron probe analysis of intact tissue (6) as well as by analyses of vesicles isolated by subcellular fractionation $(7,8)$. 
Secretory vesicles therefore could contribute to the sequestration of $\mathrm{Ca}^{2+}$. We have previously shown that purified isolated intact secretory vesicles from the neurohypophysis take up $\mathrm{Ca}^{24}$ (7) $\mathrm{Ca}^{2}+$ influx was inhibited by $\mathrm{Na}^{+}$and $\mathrm{Ca}^{2}+$ previousIy taken up by the vesicles could be released again by external $\mathrm{Na}^{+}$. It was not affected by ATP, oligomycin or ruthenium red. These properties are in accordance with a $\mathrm{Na}+/ \mathrm{Ca}^{2}+\mathrm{ex}^{2}$ change system present in the secretory vesicle membranes operating in either direction depending on the electrochemical gradients for $\mathrm{Na}^{+}$and $\mathrm{Ca}^{2+}$ across this membrane. A similar uptake system for $\mathrm{Ca}^{2+}$ in adrenal medulla secretory vesicles has previously been established $(9,33)$.

In the present paper we describe that under the same circumstances where $\mathrm{Ca}^{2+}$ efflux occurs, $\mathrm{Na}^{+}$is taken up by the vesicles. This was demonstrated by measurements of ${ }^{2}{ }^{2} \mathrm{Na}+$ uptake as well as by changes in the optical density of the vesicles. Also, we report that vesicular $\mathrm{Ca}^{2+}$ can be released by addition of external $\mathrm{Ca}^{2+}$. Thus secretory vesicles obviously are able to carry out $\mathrm{Ca}^{2+} / \mathrm{Ca}^{2+}$ exchange as well. The finding that this latter process could be completely inhibited by $\mathrm{Mg}^{2+}$ allowed us to determine the apparent $\mathrm{K}_{\mathrm{M}}$ for the $\mathrm{Ca}^{2+}$ uptake in exchange for $\mathrm{Na}^{+}$. The low value obtained $\left(7 \times 10^{-7} \mathrm{M}\right.$ free $\left(a^{2}\right)$ would be in agreement with a physiological role of the vesicular $\mathrm{Ca}^{2+}$ uptake system in neurohypophysial nerve endings. The $\mathrm{Ca}^{2+} / \mathrm{Na}^{+}$exchange and $\mathrm{Ca}^{2+}$ uptake cannot be directly correlated to ATP hydrolysis, since no ATPase activity copurified with vasopressin when two different procedures were used for isolation of the secretory vesicles.

\section{METHODS}

Isolation of Secretory Vesicles. Bovine hypophyses were obtained immediately after slaughtering at Københavns Eksportslagteri and Slagelse Andelsslagteri. The neural lobes were isolated by dissection and placed in icecold medium containing $190 \mathrm{mM}$ sucrose, $25 \mathrm{mM}$ ethyleneglycol bis ( $\beta$-amjino-ethylether) $N^{\prime}, N^{\prime}$-tetraacetic acid (EGTA), $20 \mathrm{mM} 2$ ([2-hydroxy-1,1-bis (hydroxymethyl) ethyl ]amino ethane-sulfonic acid (TES), pH 7.0 . $\mathrm{KOH}$ was used to adjust $\mathrm{pH}$. Homogenization of the tissue in the laboratory was finished not later than two hours from slaughtering.

Purified secretory vesicles were obtained by a newly developed method employing differential and density gradient centrifugation using Percoll (508) as gradient material (in isotonic media) (10), which allows to separate the secretory vesicles from mitochondria, microsomes (10), and lysosomes (this study). Such vesicles are stable on incubation in isosmolar media. Secretory vesicles recovered from the Percoll gradients (fractions $1-8$ ) and sedimented by centrifugation at $100,000 \times \mathrm{g}$ for $1 \mathrm{~h}$ were resuspended and submitted to gel filtration on Bio-Gel A 150 (BioRad) to remove Percoll. 
The specific activity of vasopressin and oxytocin in the band of vesicles selected was $37.4 \pm 8.5$ (mean, SD of 5 preparations) and $20.8 \pm 7.5$ (mean, SD of 9 preparations) $\mu \mathrm{g} \mathrm{mg}^{-1}$ protein, respectively.

In a second series of experiments, the basic medium used throughout the purification procedure was $260 \mathrm{mM}$ sucrose, 0.1 $\mathrm{mM}$ EGTA, $20 \mathrm{mM}$ TES, pH 7.0. In this case $30 \%$ Percoll was used for density gradient centrifugation $(60,000 \mathrm{gav}$ for $30 \mathrm{~min})$. A similar procedure (except for use of $0.1 \mathrm{mM}$ EGTA) has been employed by Russell (11).

In a series of experiments the secretory vesicle preparation obtained from $30 \%$ Percoll/0.1 mM EGTA gradients was further purified on a discontinuous sucrose gradient by a modification of the procedure of Vilhardt and Hope (12). The gradients were made up of $1 \mathrm{ml}$ of $2.0 \mathrm{M}, 1.4 \mathrm{M}, 1.35 \mathrm{M}$ and $1.3 \mathrm{M}$ sucrose in $0.1 \mathrm{mM}$ EGTA, $2 \mathrm{mM}$ TES, $\mathrm{pH} \mathrm{7.0.} \mathrm{The} \mathrm{material} \mathrm{was} \mathrm{layered} \mathrm{in} 1$ $\mathrm{ml}$ on top of each gradient and centrifuged in a Beckman rotor at $100,000 \times$ gav $\times 150 \mathrm{~min}\left(4^{\circ} \mathrm{C}\right)$. Fractions of $500 \mu \mathrm{l}$ were collected from the gradients by means of a peristaltic pump (Dich Instruments, DK.).

Measurement of $\mathrm{Ca}^{2+}$ Uptake. After removal of Percoll by gel filtration the secretory vesicles were centrifuged at 60,000 $\mathrm{x} g$ for $20 \mathrm{~min}$ and resuspended in $260 \mathrm{mM}$ sucrose, $20 \mathrm{mM} \mathrm{KCl}$, $0.5 \mathrm{mM}$ EGTA, $20 \mathrm{mM}$ TES, pH 7.3 (adjusted with $\mathrm{KOH}$ ) "uptake medium". Resuspension was carried out by hand in a loose-fitting Teflon-to-glass homogenizer (Vol. l $\mathrm{ml}$ ). In one set of experiments $5 \mathrm{mM}$ nitrilo-tri-acetic acid (NTA), $0.5 \mathrm{mM}$ EGTA,

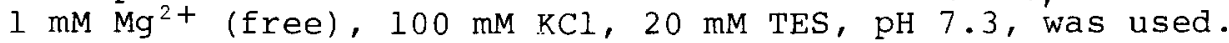

$\mathrm{Ca}^{2+}$ was included in the "uptake medium" to give various free $\mathrm{Ca}^{2}+$ concentrations calculated as decribed (13), taking into account the known stability constants (14). The calculated free $\mathrm{Ca}^{2+}$ concentrations were checked by use of a calcium specific electrode, donated by Professor W.Simon, zürich, and the calcium binding constant and EGTA concentration were corrected by the use of a scatchard plot according to the method of Bers (15). ${ }^{45} \mathrm{Ca}^{2+}$ was added to the solutions to give a specific activity of $5 \mu \mathrm{Ci} / \mathrm{mmole}^{\mathrm{Ca}}{ }^{2+}$. The uptake medium (150 $\mu \mathrm{I}$ ) was kept at $30^{\circ} \mathrm{C}$ for $5 \mathrm{~min}$ before addition of secretory vesicles $(50 \mu \mathrm{g})$ in a volume of $50 \mu \mathrm{l}$. After incubation (10 min unless otherwise stated) the vesicles were separated from the medium by filtration (Millipore cellotate filters, pore size $0.2 \mathrm{\mu m})$. The filters were washed with $2 \times 5 \mathrm{ml}$ of icecold uptake medium described above, containing no $\mathrm{Ca}^{2+}$, placed in counting vials, dried at $80^{\circ} \mathrm{C}$ for $1 \mathrm{~h}$, and cooled to room temperature. The filters were counted in $10 \mathrm{ml}$ of Lumagel scintillation fluid. The samples were left for $24 \mathrm{~h}$ at $4^{\circ} \mathrm{C}$ before counting. In certain experiments $130 \mathrm{mM} \mathrm{KCl}$ or various concentrations of $\mathrm{NaCl}$ were used in the incubation medium to replace sucrose. 
Measurement of $\mathrm{Ca}^{2+}$ Efflux. Secretory vesicles preloaded with $\mathrm{Ca}^{2+}$ were prepared in the following way: Secretory vesicles were incubated to take up calcium in a medium containing $10^{-4} \mathrm{M}$ free $\mathrm{Ca}^{2}+,{ }^{45} \mathrm{Ca}^{2}+(5 \mu \mathrm{Ci} / \mathrm{mmol}), 130 \mathrm{mM} \mathrm{KCl}, 0.5 \mathrm{mM}$ EGTA and $20 \mathrm{mM}$ TES ( $\mathrm{pH} 7.3$ ) for $15 \mathrm{~min}$ at $30^{\circ} \mathrm{C}$. These vesicles were then diluted tenfold in a medium containing either $130 \mathrm{mM} \mathrm{NaCl}$, $130 \mathrm{mM} \mathrm{KCl}$, or $10^{-4} \mathrm{M}$ free $\mathrm{Ca}^{2+}$ plus $130 \mathrm{mM} \mathrm{KCl}$. In addition, these media contained $0.5 \mathrm{mM}$ EGTA and $20 \mathrm{mM}$ TES $\mathrm{pH} 7.3$. The $\mathrm{pH}$ was adjusted with KOH and the temperature during further incubation was $30^{\circ} \mathrm{C}$. Filtration and washing of the filters as well as the determination of ${ }^{45} \mathrm{Ca}^{2+}$ was done as described for uptake. In a series of experiments free $\mathrm{Mg}^{2+}\left(10^{-6}-10^{-3} \mathrm{M}\right)$ (calculated as described for free $\mathrm{Ca}^{2+}$ ) was present in the medium during efflux.

Measurement of $\mathrm{Na}^{+}$Uptake. Samples preloaded by $\mathrm{Ca}^{2+}$ as $\mathrm{de}^{-}$ scribed for measurement of $\mathrm{Ca}^{2+}$ efflux were diluted $1: 10$ in a medium containing various concentrations of NaCl labelled with ${ }^{22} \mathrm{Na}^{+}$. The activity of ${ }^{22} \mathrm{Na}^{+}$in the medium was $0.2 \mu \mathrm{Ci} / \mathrm{ml}$. In addition $\mathrm{KCl}$ was included to obtain a final total concentration of $130 \mathrm{mM}$ salt and $1 \mathrm{mM} \mathrm{MgCl}_{2}$. The filters were washed 5 times with the same medium (without isotope) to obtain blanks of 0.05 ${ }_{0}$ of totals. Using this procedure the amount of protein needed was $500 \mathrm{Hg}$ to obtain a doubling of the background. ${ }^{2} \mathrm{Nat}^{+}$was counted in a $\gamma$-counter (Searle).

During all isolation and incubation procedures the total osmolality of the buffers and media was kept between 315 and 3.20 mosmol $/ \mathrm{kg}$. All experiments were finished within $16 \mathrm{~h}$ from slaughtering of the animals.

Measurements of Vasopressin, Oxytocin, and Protein. Vasopressin was measured by radioimmunoassay as described in (16), oxytocin by a similar assay. Protein was determined by the use of fluorescamine (Fluram, Roche (17)).

Enzyme Assays. ATPases were measured as described in (18). GLDH was assayed as described in (10), and beta glucuronidase by the method of Price and Dance (19). Acid phosphatase was measured as described in (20), using $\beta$-glycerophosphate as substrate. Malakit green (Fluka) was used for determination of inorganic phosphate liberated after precipitation of protein in 5 \% $\mathrm{H}_{2} \mathrm{SO}_{4}(21)$.

\section{MATERIALS}

${ }^{22} \mathrm{Na}^{+} \mathrm{Cl}$ and ${ }^{45} \mathrm{Ca}^{2}+\mathrm{Cl}^{2}$ were obtained from Amersham. Lumagel was from Lumac System AG, Basel. Calmodulin was from Fluka, batch No. 233745682 . Percoll was a product of Pharmacia, Sweden, which was dialyzed for $2 \times 12$ h against the appropriate medium before use.

All other reagents were of analytical grade. 


\section{RESULTS}

Effects of $\mathrm{K}^{+}, \mathrm{Na}^{+}$, and $\mathrm{Ca}^{2}+$ on the efflux of $\mathrm{Ca}^{2+}$. The efflux of $\mathrm{Ca}^{2+}$ from preloaded secretory vesicles in the presence of various cations is shown in Fig. 1. In the presence of $\mathrm{KCl}$ no efflux was observed. Addition of $\mathrm{Ca}^{2+}$ to a concentration of $10^{-4} \mathrm{M}$ (free) or substituting $\mathrm{KCl}$ by $\mathrm{NaCl}$ induced $\mathrm{Ca}^{2+}$ efflux, which was linear within $5 \mathrm{~min}$. About 50 \% of the $\mathrm{Ca}^{2+}$ taken up during preloading remained in the vesicles. This experiment indicates that $\mathrm{Na}^{+}$as well as $\mathrm{Ca}^{2+}$ are able to release $\mathrm{Ca}^{2+}$ from preloaded vesicles, probably by exchange of intravesicular $\mathrm{Ca}^{2+}$ with extravesicular $\mathrm{Ca}^{2+}$. $\mathrm{Mg}^{2}+$ had little effect on $\mathrm{Na}^{+}$induced $\mathrm{Ca}^{2}+$ efflux $\left(\mathrm{Ca}^{2}+\right.$ content after 20 min was $48 \pm 8 \%$ of control $(\mathrm{n}=4)$ in the presence of $\left.1 \mathrm{mM} \mathrm{Mg}^{2+}\right)$.

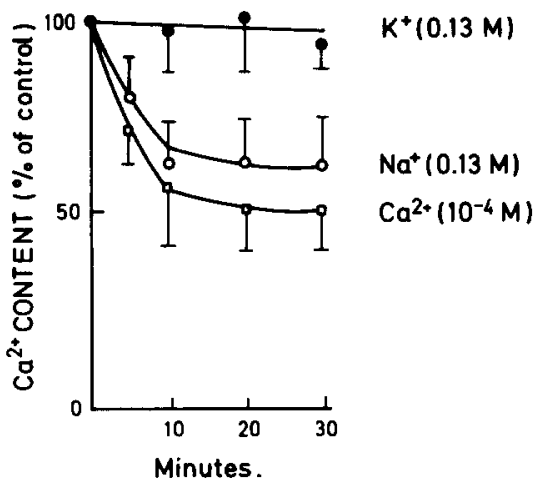

Fig. $1 \mathrm{Ca}^{2+}$ and $\mathrm{Na}^{+}$induced $\mathrm{Ca}^{2}+$ efflux from secretory vesicles. Secretory vesicles were first incubated at $30^{\circ} \mathrm{C}$ in a medium containing $130 \mathrm{mM} \mathrm{KCl}, 0.5 \mathrm{mM} \mathrm{EGTA}, 20 \mathrm{mM} T E S, \mathrm{pH} 7.3$ and $\mathrm{Ca}^{2+}$ labelled with ${ }^{45} \mathrm{Ca}^{2+}$ (Free $\mathrm{Ca}+$ concentration of $10^{-4} \mathrm{M}$ ). After 15 min of incubation, the samples were diluted 1:10 in the same medium containing no $\mathrm{Ca}^{2+}\left(\mathrm{K}^{+},-\right)$, in the medium containing $10^{-4} \mathrm{M} \mathrm{Ca}^{2}+$, but no ${ }^{45} \mathrm{Ca}^{2}+\left(\mathrm{Ca}^{2+}\right.$, 口) or j.n a medium containing no $\mathrm{Ca}^{2+}$ and $130 \mathrm{mM} \mathrm{NaCl}$ instead of $\mathrm{KCl}\left(\mathrm{Na}^{+}, 0\right)$. At various time points the samples were filtered and counted as described in the Methods section. The values represent the mean of 3 expts, bars $=\mathbf{S D}$. $100 \%$ corresponds to $13.5 \pm 2.8 \mathrm{nmol} \mathrm{Ca}^{2+} /$ mg protein.

The stability of the vesicles was the same in the different incubation procedures. This was shown by incubating the secretory vesicles under the same conditions for $1 \mathrm{~h}$ followed by centrifugation at $28,000 \mathrm{~g}$ av $\times 15 \mathrm{~min}$. Incubation in the medium containing $130 \mathrm{mM} \mathrm{KCl}$ caused a release of $23 \% \pm 4.7$ 
(S.D., $n=3$ ) of vesicular vasopressin. After incubation in media containing $130 \mathrm{mM} \mathrm{Na}+26 \% \pm 1$ (S.D. $\mathrm{n}=3$ ) of hormone was found in the supernatant. Addition of $\mathrm{Ca}+$ to the medium did not change the stability $(24 \% \pm 3$ release, independently of the monovalent cation). These figures should be compared with a release of $21 \%$ when the vesicles were incubated under similar conditions in the isolation buffer.

Inhibition of $\mathrm{Ca}^{2+}$ induced $\mathrm{Ca}^{2}+$ efflux by $\mathrm{Mg}^{2+}$. Test of effect of calmodulin. Fig. 2 shows that $\mathrm{Mg}^{2+}$ strongly inhibited the $\mathrm{Ca}^{2+}$ efflux from ${ }^{4} \mathrm{Ca}^{2}+$ preloaded secretory vesicles induced by $\mathrm{Ca}^{2+}$. The $\mathrm{Ca}^{2+}$ retained in the vesicles was determined after 10 or 20 minutes at $30^{\circ} \mathrm{C}$ in the presence of various free concentrations of $\mathrm{Mg}^{2+}$ (see Methods). The inhibition was almost complete above $0.1 \mathrm{mM}$ free $\mathrm{Mg}^{2+}$.

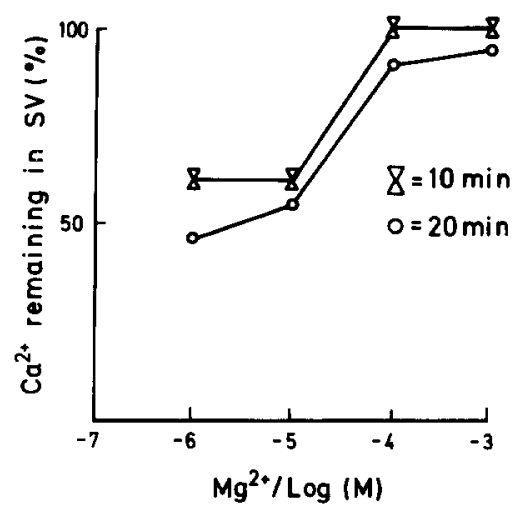

Fig. 2 Inhibition of $\mathrm{Ca}^{2+} / \mathrm{Ca}^{2+}$ exchange by $\mathrm{Mg}^{2+}$. Secretory vesicles (SV) were preincubated in the same way as described in legend to Fig. 1. The samles were then diluted $1: 10$ in the same medium containing $\mathrm{Ca}^{2}+\left(10^{-4} \mathrm{M}\right.$ free) without ${ }^{45} \mathrm{Ca}^{2}+$ and including $\mathrm{Mg}^{2}+$ to give the free concentrations indicated. After a further incubation for 10 or $20 \mathrm{~min}$. the samples were filtered and counted as described in the Methods section.

The fact that $\mathrm{Ca}^{2+}$ induced $\mathrm{Ca}^{2}+$ release $\left(\mathrm{Ca}^{2}+/ \mathrm{Ca}^{2}+\right.$ exchange) can be inhibited by $\mathrm{Mg}^{2+}$ and that $\mathrm{Na}^{+} / \mathrm{Ca}^{2+}$ exchange is not affected by $\mathrm{Mg}^{2+}$ (see also 7) allowed to measure $\mathrm{Ca}^{2+}$ influx selectively.

Fig. 3 shows a double reciprocal plot of the $\mathrm{Ca}^{2}+$ concentration dependence for $\mathrm{Ca}^{2}+$ uptake measured in the presence of $1 \mathrm{mM}$ free $\mathrm{Mg}^{2}+$. The data could be fitted to a straight line $\left(R^{2}=0.975\right)$, data from 3 expts. 


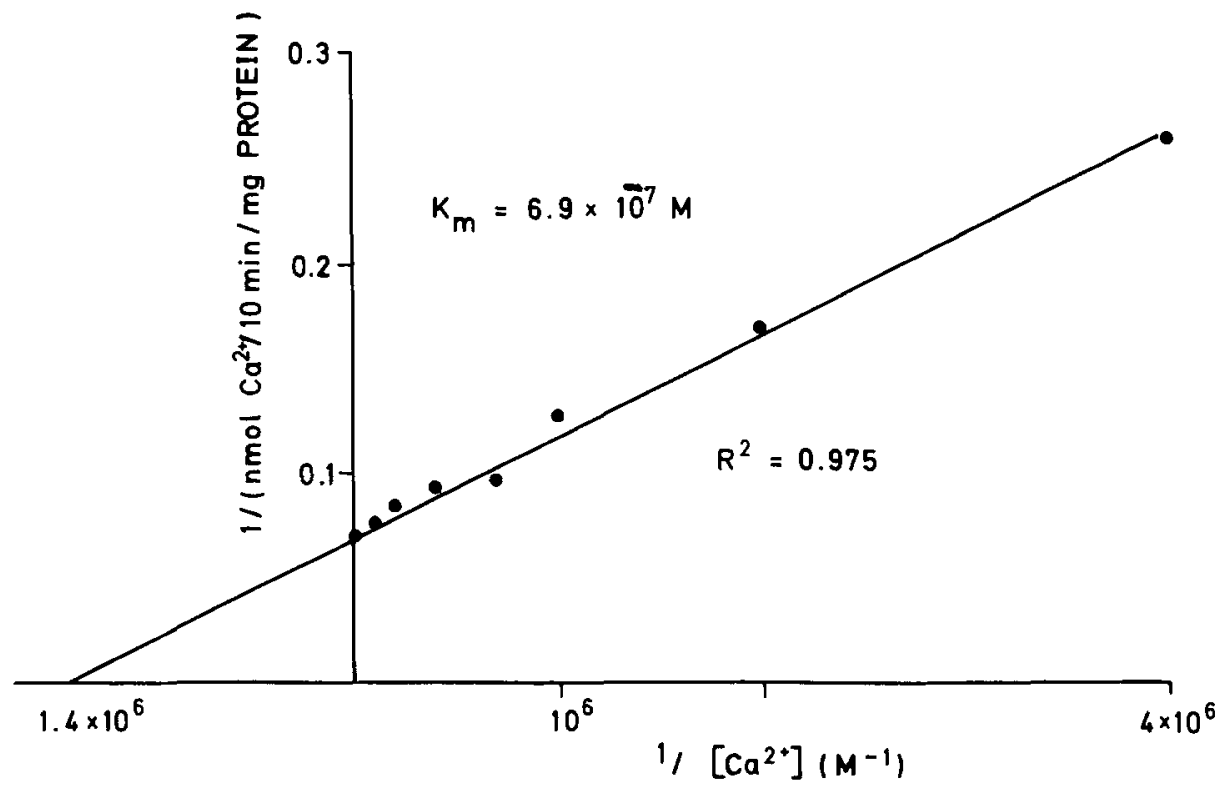

Fig. $3 \mathrm{Ca}^{2}+$ uptake into secretory vesicles in the presence of I $\mathrm{mM} M \mathrm{~g}^{2}+$. Double reciprocal plot of initial velocity of $\mathrm{Ca}^{2+}$ uptake by secretory vesicles as a function of the $\mathrm{Ca}^{2}+$ concentration. The buffer used was the same as described for the $\mathrm{Ca}^{2+}$ loading procedure in Fig. 1 , containing in addition $1 \mathrm{mM} \mathrm{Mg}^{2+}$ (free). The initial velocity was calculated on the basis of measurements of $\mathrm{Ca}^{2}+$ uptake after 5 and $8 \mathrm{~min}$. Within these time periods the uptake was linear with time. It was expressed per $10 \mathrm{~min}$ period. $\mathrm{Ca}^{2+}$ uptake was measured as described in the Methods section.

Incubation was carried out at $30^{\circ} \mathrm{C}$ in a medium containing 130 $\mathrm{mM} \mathrm{KCl}, 20 \mathrm{mM}$ TES, $0.5 \mathrm{mM}$ EGTA, $\mathrm{pH} 7.3$ including $1 \mathrm{mM} \mathrm{Mg}^{2+}$ (free). The incubation was carried out not longer than $8 \mathrm{~min}$, i.e. the period in which uptake was linear with time (7) and the $\mathrm{Ca}^{2+}$ uptake per $10 \mathrm{~min}$ was calculated. The $\mathrm{K}_{\mathrm{m}}$ value was $6.9 \times 10^{-7}$ and $V_{\max }$ was $1.47 \mathrm{nmol} / \mathrm{mg} \times \mathrm{min}$. Using $5 \mathrm{mM} \mathrm{NTA}$, $0.5 \mathrm{mM}$ EGTA, $100 \mathrm{mM} \mathrm{KCl}$ and $20 \mathrm{mM}$ TES, $\mathrm{pH} 7.3, \mathrm{a} \mathrm{K}_{\mathrm{m}}$ value of $1.2 \times 10^{-6} \mathrm{M}$ was found $\left(\mathrm{R}^{2}=0.95\right)$. The addition of calmodulin to the incubation medium before addition of $\mathrm{Ca}^{2}+$ did not change the kinetic properties of the $\mathrm{Ca}^{2+}$ uptake. In the presence of $1 \mathrm{\mu g}$ calmodulin/l00 $\mu \mathrm{g}$ secretory vesicle protein, the $K_{m}$ was $6.4 \times 10^{-7}$. The $V_{\max }$ was $1.44 \mathrm{nmol} / \mathrm{mg} \times \mathrm{min}\left(\mathrm{R}^{2}=\right.$ 0.970 for data from 3 expts.). This is in accordance with results of earlier experiments in which trifluoperazine, an inhibitor of calmodulin linked reactions, was also ineffective 
Uptake of ${ }^{22} \mathrm{Na}^{+}$. The $\mathrm{Ca}^{2+}$ preloaded secretory vesicles (see Methodsl were diluted $1: 10$ in a medium containing $20 \mathrm{mM}$ TES, $0.5 \mathrm{mM}$ EGTA in addition to $\mathrm{KCl}$ and $\mathrm{NaCl}$ (labelled with ${ }^{22} \mathrm{Na}^{+}$) in a total concentration of $130 \mathrm{mM}$ giving a final osmolality of approx. $320 \mathrm{mosmol} / \mathrm{kg}$. In this way $\mathrm{NaCl}$ and $\mathrm{KCl}$ concentrations were varied to give the final NaCl concentrations on the abscissa in Fig. 4 at a constant ionic strength. Nat uptake increased linearly up to about $20 \mathrm{mM} \mathrm{Na}^{+}$, at higher concentrations the uptake levelled off.

If the data were plotted as a double reciprocal plot, the experimental points from individual experiments did not fit well using linear regression analysis ( $\mathrm{R}^{2}$ about 0.830$)$. When data from 6 experiments were analyzed, however, half maximal $\mathrm{Na}^{+}$ uptake occurred with $20 \mathrm{~mm} \mathrm{Nat}$, regression coefficient 0.988 .

$\mathrm{Na}^{+}$uptake as indicated by decrease in optical density. As further evidence for Nat uptake by the secretory vesicles, the optical density was measured during incubation of $\mathrm{Ca}^{2}+$ preloaded secretory vesicles in presence of $130 \mathrm{mM} \mathrm{NaCl}$. A decrease should be an indication of swelling due to increased intravesicular osmotic pressure caused by more $\mathrm{Na}^{+}$taken up than $\mathrm{Ca}^{2+}$ released $(7$, compare 22,23$)$.

Neurohypophysial secretory vesicles respond to changes in the osmolality of the media. This was determined by incubation of the vesicles in $0.5 \mathrm{mM}$ EGTA, $20 \mathrm{mM}$ TES, $\mathrm{pH} 7.3$, including various amounts of sucrose. The optical density at $560 \mathrm{~nm}$ decreased with sucrose media below $200 \mathrm{mosmol} / \mathrm{kg}$ (data not shown). This is in agreement with the osmotic stability measured by vasopressin efflux published earlier (10).

Fig. 5 shows the change in optical density at $560 \mathrm{~nm}$ of a suspension of secretory vesicles preloaded with $\mathrm{Ca}^{2+}$ (see $\mathrm{Me}-$ thods) incubated at $30^{\circ} \mathrm{C}$ in presence of $130 \mathrm{mM} \mathrm{KCl}$ or $\mathrm{NaCl}$ with or without $10^{-4} \mathrm{M}$ free $\mathrm{Ca}^{2+}$ present. $1 \mathrm{mM} \mathrm{Mg}^{2}+$ was present in all media. In addition to the ions $20 \mathrm{mM}$ TEs and 0.5 $\mathrm{mM}$ EGTA, $\mathrm{pH}$ 7.3, were included in the assay medium. Air was used as reference. The optical densities were recorded at intervals of $1 \mathrm{~min}$ to avoid local heating. Starting from a level of 0.2 the extinction decreased when $130 \mathrm{mM}$ NaCl was included in the incubation medium. The optical density in presence of $130 \mathrm{mM} \mathrm{NaCl}$ was 0.1 after $60 \mathrm{~min}$, compared with 0.190 in the presence of $130 \mathrm{mM} \mathrm{KCl}$ (control). The small reduction in the optical density in the presence of $\mathrm{KCl}$ (130 mM) was identical in the presence or in the absence of external $\mathrm{Ca}^{2}+\left(10^{-4} \mathrm{M}\right)$. $10^{-4} \mathrm{M} \mathrm{Ca}^{2}+$ slightly reduced the effect of $\mathrm{Na}^{+}$. It should be recalled here that within $1 \mathrm{~h}$ no significant difference of vasopressin release could be detected for the different media (see $\mathrm{p}^{+} ;$;. 


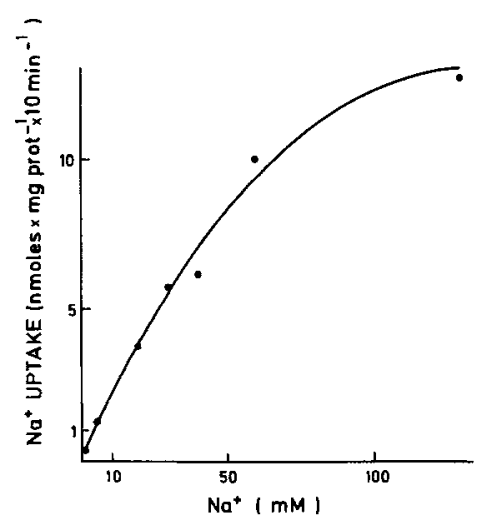

Fig. 4

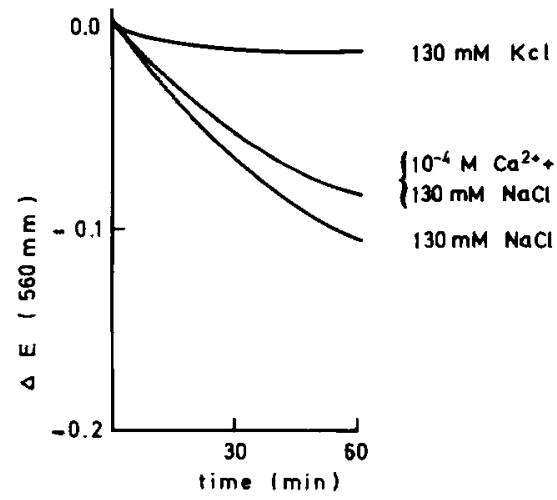

Fig. 5

Fig. 4. $\mathrm{Na}^{+}$uptake into SV preloaded with $\mathrm{Ca}^{2+}$. SV were preincubated for $15 \mathrm{~min}$ in a medium containing $10^{-4} \mathrm{M} \mathrm{Ca}+, 130$ $\mathrm{mM} \mathrm{KCl}, 0.5 \mathrm{mM}$ EGTA, $20 \mathrm{mM}$ TES, $\mathrm{pH} 7.3$. At $15 \mathrm{~min}$. the samples were diluted $1: 10$ in a medium containing $0.5 \mathrm{mM}$ EGTA, $20 \mathrm{mM}$ TES, $\mathrm{pH} 7.3$, including increasing amounts of NaCl containing ${ }^{2} \mathrm{Na}^{+}$. KCl was added to give a final ( $\mathrm{NaCl}+\mathrm{KCT}$ ) concentration of $130 \mathrm{mM}$ corresponding to an osmolar concentration of $320 \mathrm{mOsmol} / \mathrm{kg}$. After $10 \mathrm{~min}$ the samples were filtered, washed with $2 \times 5 \mathrm{ml} 130 \mathrm{mM} \mathrm{NaCl}, 0.5 \mathrm{mM}$ EGTA, $20 \mathrm{mM}$ TES, pH 7.3 , and the radioactivity retained was determined (see Methods section) (means of 4 expts.). $\mathrm{Na}^{+}$uptake at $130 \mathrm{mM} \mathrm{NaCl}$ was $12.9 \mathrm{nmol} \pm$ 4.8 per $10 \mathrm{~min}$ (S.D., $\mathrm{n}=4$ ).

Fig. 5. Nat uptake indicated by change in optical density. Secretory vesicles $(75 \mu \mathrm{g})$ were preincubated at $30^{\circ} \mathrm{C}$ in $130 \mathrm{~mm}$ $\mathrm{KCl}, 10^{-4} \mathrm{M} \mathrm{Ca}^{2+}, 0.5 \mathrm{mM}$ EGTA, $20 \mathrm{mM}$ TES, $\mathrm{pH} 7.3$ for $15 \mathrm{~min}$ in a volume of $0.5 \mathrm{ml}$. At time 0 they were diluted $1: 10$ in media containing $130 \mathrm{mM} \mathrm{KCl}, 130 \mathrm{M} \mathrm{NaCl} \times 10^{-4} \mathrm{M} \mathrm{Ca}^{2+}$ or 130 $\mathrm{mM} \mathrm{NaCl}$. The optical density at $560 \mathrm{~nm}$ was read at intervals to avoid local heating of the samples. All media contained $1 \mathrm{mM} \mathrm{Mg}{ }^{2+}$ to inhibit $\mathrm{Ca}^{2+}$ induced efflux of $\mathrm{Ca}^{2+}$.

The incubation of secretory vesicles not preloaded with $\mathrm{Ca}^{2+}$ also changed their optical densities when added to $130 \mathrm{mM}$ $\mathrm{NaCl}$, probably due to the endogenous $\mathrm{Ca}^{2+}$ present in isolated secretory vesicles (7).

Arpase activities in the secretory vesicle fraction. $\mathrm{Na}^{+} / \mathrm{Ca}^{2+}$ exchange is a well-known process taking place in the cell membranes of nerve and muscle cells (1). To exclude that the $\mathrm{Na}^{+} /$ $\mathrm{Ca}^{2}+$ exchange system described here might be due to presence of cell membrane fragments in our preparation we determined $\mathrm{Na}^{+} / \mathrm{K}^{+}$ATPase distribution in the gradients used for secretory vesicle isolation. We also measured $\mathrm{Mg}^{2+}$ ATPase activities 
which have been described to occur in neurohypophysial secretory vesicles (24) although its presence has not been found in an earlier investigation (12).

Discribution on 508 Percoll gradients containing $25 \mathrm{mM}$ EGTA. In the gradients used in the main part of this work (50\% Percoll in a medium containing $190 \mathrm{mM}$ sucrose, $25 \mathrm{mM}$ EGTA and 20 $\mathrm{mM}$ TES, $\mathrm{pH} 7.0$, see Methods), we did not find any $\mathrm{Mg}^{2}+\mathrm{ATPase}$ activity in the secretory vesicle fractions (band centered around fraction 5, see protein profile, Fig. 6B) which contains vasopressin, oxytocin, and neurophysin (see 10). The $\mathrm{Mg}^{2}+\mathrm{ATP}-$ ase was assayed as described in the Methods section at a free $\mathrm{Mg}^{2}+$ concentration of $1 \mathrm{mM}$. The addition of $10^{-6}$ or $10^{-4}$ free $\mathrm{Ca}^{2}+$ to the assay changed neither the ATPase activity nor its pattern of distribution. Of the total $\mathrm{Mg}^{2}+$ ATPase activity present in the homogenate only $0.38 \% \pm 0.19$ (S.D. $n=4$ ) was found in the secretory vesicles (fractions 1-7, Fig. 6B). The relative specific activity was $0.09 \pm 0.04$ (S.D. $n=4$ ) (Table 1 ).

Table 1. Distribution of ATPases in secretory vesicle fractions recovered from 3 types of density gradients (means \pm S.D.)

\begin{tabular}{|c|c|c|c|c|c|}
\hline GRADIENT & $\begin{array}{l}\text { Pooled } \\
\text { fraction } \\
\text { No. }\end{array}$ & $\mathrm{n}$ & & $\mathrm{Mg}^{2}+$ ATPase & $\mathrm{Na}^{+} / \mathrm{K}^{+}$ATPase \\
\hline $\begin{array}{l}50 \% \text { Percoll } \\
25 \mathrm{mM} \mathrm{EGTA}\end{array}$ & $1-7$ & 4 & $\begin{array}{c}\text { SA } \\
\text { R.S.A. } \\
\& \text { of Total } \\
\text { Recovery }\left(\frac{8}{\circ}\right)\end{array}$ & $\begin{array}{l}0.24 \pm 0.3 \\
0.09 \pm 0.04 \\
0.38 \pm 0.19 \\
101 \pm 16\end{array}$ & $\begin{array}{c}<0.08 \pm 0.06 * \\
<0.16 \pm 0.09 \\
<0.42 \pm 0.3 \\
91 \pm 17\end{array}$ \\
\hline $\begin{array}{ll}308 & \text { Percoll } \\
0.1 & \mathrm{mM} \\
\end{array}$ & $1-12$ & 4 & $\begin{array}{c}\text { SA } \\
\text { R.S.A. } \\
\text { of of Total } \\
\text { Recovery }(\%)\end{array}$ & $\begin{array}{c}2.1 \pm 0.6 \\
0.72 \pm 0.5 \\
5.1 . \pm 2.0 \\
113 \pm 28\end{array}$ & $\begin{array}{c}<0.02 \pm 0.03 \\
<0.04 \pm 0.01 \\
<0.4 \pm 0.2 \\
126 \pm 25\end{array}$ \\
\hline $\begin{array}{l}2.0-1.3 \mathrm{M} \\
\text { Sucrose } \\
0.1 \text { mM̈ EGTA }\end{array}$ & $1-10$ & 3 & $\begin{array}{c}\text { SA } \\
\text { R.S.A. } \\
\text { of TotaI } \\
\text { Recovery (\%) }\end{array}$ & $\begin{array}{l}0.2 \pm 0.1 \\
0.1 \pm 0.07 \\
1.1 \pm 0.8 \\
110 \pm 9\end{array}$ & \\
\hline
\end{tabular}

*In 2 out of 4 expts. $\mathrm{Na}^{+} / \mathrm{K}^{+}$ATPase activity could not be detected with the assay sensitivity ( 3 nmol ATP hydrolyzed; 21) $\mathrm{SA}=$ Specific Activity ( $\mu \mathrm{mol} / \mathrm{h} / \mathrm{mg})$

R.S.A. (Relative Specific Activity) $=\frac{\frac{g}{g} \text { recovered activity }}{\frac{o}{6} \text { recovered protein }}$ $s$ of Total $=8$ of total activity in homogenate recovered in secretory vesicles 
GRADIENT : $50 \%$ Percoll, 25 m M EGTA
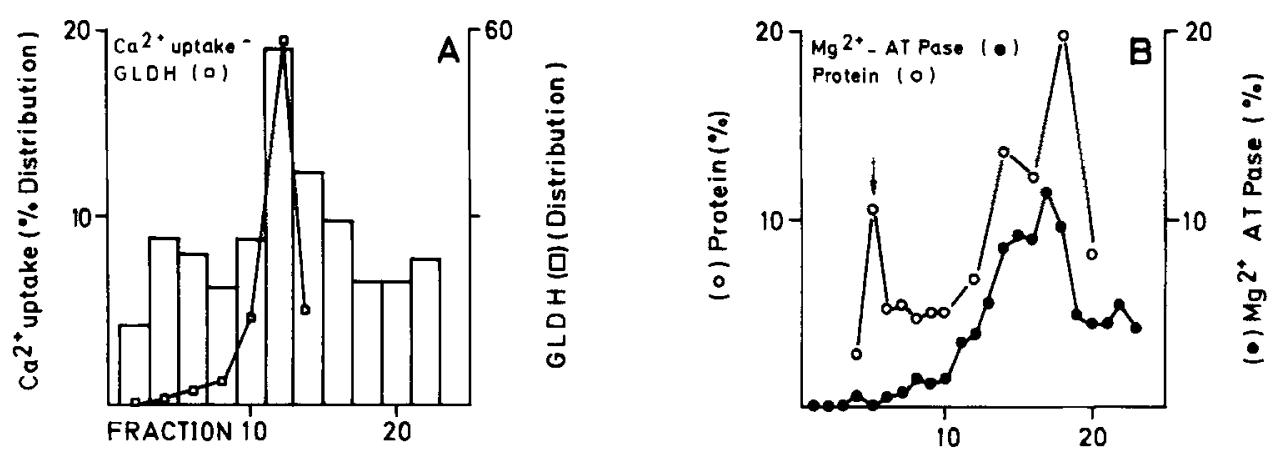

GRADIENT : $30 \%$ Percoll, $0.1 \mathrm{mM}$ EGTA
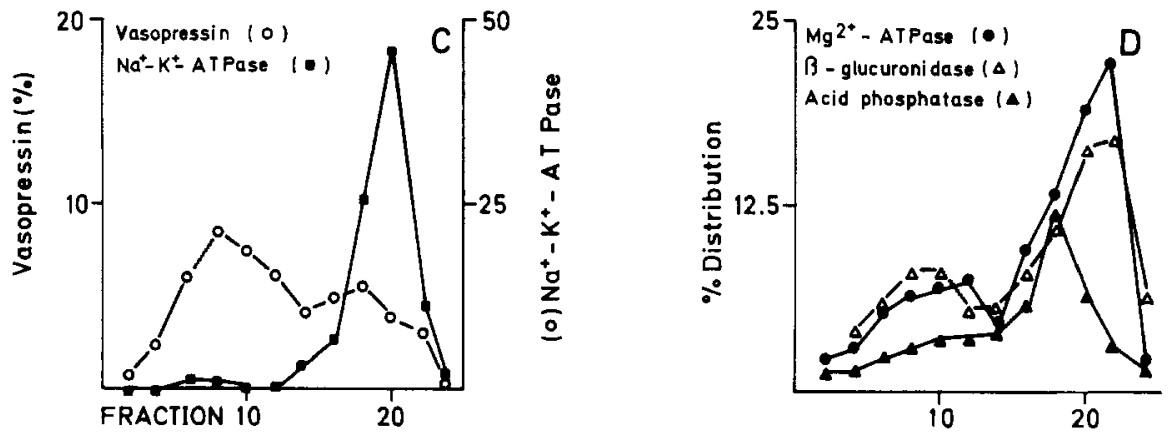

Discontinous sucrose gradient, $0.1 \mathrm{mM}$ EGTA after isolation on $30 \%$ Percoll, $0.1 \mathrm{mM}$ EGTA
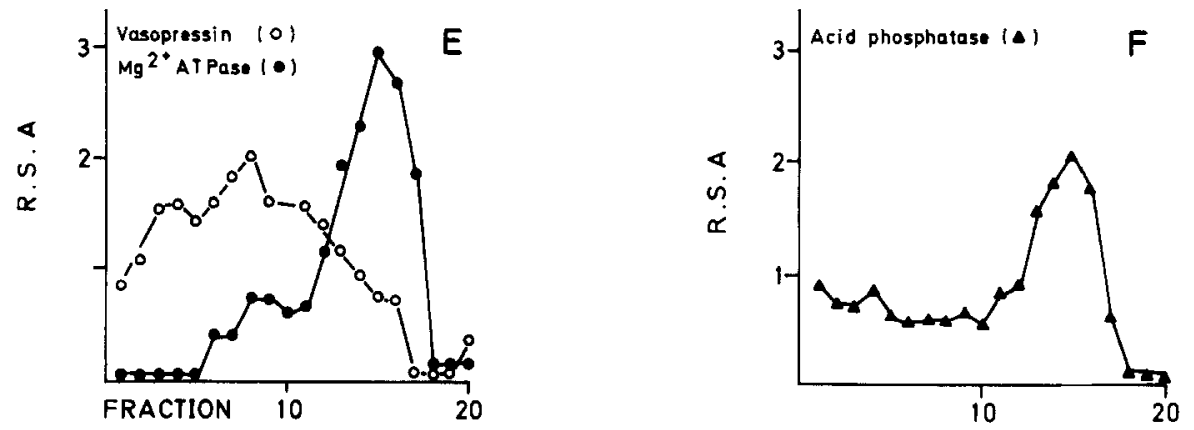

Fig. 6. Distribution of ATPases and other enzymes and markers as well as protein on gradients composed of 
A, B 508 Percoll, $25 \mathrm{mM}$ EGTA, $20 \mathrm{mM}$ TES ( $\mathrm{pH} 7.0$ ) and $130 \mathrm{mM}$ sucrose. C, D $30 \%$ Percoll, $0.1 \mathrm{mM}$ EGTA, $20 \mathrm{mM}$ TES ( $\mathrm{pH} 7.0$ ) and $260 \mathrm{mM}$ sucrose. $\mathrm{E}, \mathrm{F}$ Discontinuous sucrose $(2.0-1.3 \mathrm{M}), 0.1 \mathrm{mM}$ EGTA, $20 \mathrm{mM}$ TES $(\mathrm{pH} 7.0)$.

Material placed on 508 as well as 308 Percoll gradient: Fraction $\mathrm{P}_{2}$ (see 10); material placed on discontinuous sucrose gradient: Fraction 1-12 from $30 \%$ Percoll gradient.

Recoveries for acid phosphatase: $86 \pm 128 \quad(n=3)$. Recoveries for beta glucuronidase: $68 \pm 10 \%(n=3)$

Relative specific activity (R.S.A.) is : $\frac{8 \text { recovered activity }}{8 \text { recovered protein }}$ The data represent means of at least 3 expts. in each figure.

Also, no $\mathrm{Na}^{+} / \mathrm{K}^{+}$ATPase was found in the secretory vesicle region (Table I). This is in accordance with the original paper describing the isolation of secretory vesicles on isosmolar Percoll gradients (10).

The distribution of $\mathrm{Ca}^{2+}$ accumulation by fractions recovered from the $50 \%$ Percoll gradient is given in Fig. $6 \mathrm{~A}$. The incubation $\left(30^{\circ} \mathrm{C}\right)$ was carried out for $10 \mathrm{~min}$ with $10^{-4} \mathrm{M}$ free $\mathrm{Ca}^{2+}$. Each fraction was diluted $1: 20$ into the assay medium containing $260 \mathrm{mM}$ sucrose, $1 \mathrm{mM} \mathrm{MgCl} 2,20 \mathrm{mM} \mathrm{TES}, \mathrm{pH} \mathrm{7.0.} \mathrm{The} \mathrm{final}$ EGTA concentration was $1.25 \mathrm{mM}$. Two peaks appeared. One coinciding with the secretory vesicle fraction and the other with localization of the mitochondrial marker (glutamate dehydrogenase). It has been described earlier that secretory vesicles accumulate $\mathrm{Ca}^{2}+$ even in presence of ruthenium red and that this process is not stimulated by ATP (7). By contrast $\mathrm{Ca}^{2+}$ uptake into neurohypophysial mitochondrial fractions was stimulated by ATP (7). From the experiments described it can be concluded that the secretory vesicles prepared in these gradients neither contain $\mathrm{Mg}^{2}+$ ATPase nor $\mathrm{Na}+/ \mathrm{K}^{+}$ATPase, nor exhibit an ATP stimulated $\mathrm{Ca}^{2+}$ uptake, but take up $\mathrm{Ca}^{2+}$ as a consequence of a $\mathrm{Na}^{+}$gradient $\left(\left[\mathrm{Na}^{+}\right]_{i}>\left[\mathrm{Na}^{+}\right]_{0}\right)$.

Distribution on $30 \%$ Percoll gradients containing $0.1 \mathrm{mM}$ EGTA. It could be argued that the high concentration of EGTA used during subfractionation might cause inactivation of the ATPase and thus explain the extremely low amount of $\mathrm{Mg}^{2+}$ ATPase or $\mathrm{Na}^{+} / \mathrm{K}^{+}$ATPase activity in the secretory vesicle fraction.

To test this possibility we reduced the concentration of EGTA to $0.1 \mathrm{mM}$ in the buffered media used for the isolation of the secretory vesicles (see Methods). 308 Percoll was used instead of $50 \%$ to obtain a proper separation in the gradients at lower ionic strength (11) (see Methods).

The distribution of $\mathrm{Na}^{+} / \mathrm{K}^{+}$ATPase on the $30 \%$ Percoll gradients containing $0.1 \mathrm{mM}$ EGTA (Fig. 6C) was not different from that 
reported earlier (10) using 508 Percoll as a gradient material and $25 \mathrm{mM}$ EGTA in the medium. No significant activity was present in the secretory vesicle fractions (Fig. 6C, Table I). The relative specific activity $(0.04)$ and the percentage of total $\mathrm{Na}^{+} / \mathrm{K}^{+}$ATPase activity found in the secretory vesicles $(0.4)$ were in the same low order of magnitude compared with the original work on secretory vesicle isolation on these gradients $(10)$.

As opposed to the distribution of $\mathrm{Na}^{+} / \mathrm{K}^{+}$ATPase in both types of gradients, in the presence of $0.1 \mathrm{mM}$ EGTA, using a $30 \%$ Percoll gradient, a peak of $\mathrm{Mg}^{2+}$ ATPase activity was apparent in the secretory vesicle fraction (Fig. 6D, Table I). The specific activity in the secretory vesicle fraction (No. 1-12) was $2.1 \mu \mathrm{mol} / \mathrm{h} / \mathrm{mg} \pm 0.6$ (S.D., $\mathrm{n}=3$ ) which should be compared with the value of $0.24 \mu \mathrm{mol} / \mathrm{h} / \mathrm{mg} \pm 0.3$ (S.D. $\mathrm{n}=4$ ) for the fractions 1-7 in Fig. 6B (50\% Percoll, $25 \mathrm{mM} \mathrm{EGTA})$. The high amount of $\mathrm{Mg}^{2+}$ ATPase activity present in secretory vesicles when prepared on $0.1 \mathrm{mM}$ EGTA/30\% Percoll gradients might represent a lysosomal contamination since acid phosphatase and $\beta$-glucuronidase were distributed in the same way as the $\mathrm{Mg}^{2+} \mathrm{ATPase}$ (Fig. 6D). The low amount of $\mathrm{Mg}^{2+}$ ATPase activity in the secretory vesicle fractions shown in Fig. 6B compared to Fig. 6D is not an effect of the high EGTA concentration employed for the preparation of the secretory vesicles. If $25 \mathrm{mM}$ EGTA was added to the vesicle fractions obtained from the gradients in Fig. 6C (containing $0.1 \mathrm{mM}$ EGTA) before the assay, no change in $\mathrm{Mg}^{2+}$ ATPase activity was observed. The specific ATPase activity for the fractions containing secretory vesicles prepared in $0.1 \mathrm{mM}$ EGTA (Fig. 6C, fractions 4-12, pooled) was $2.1 \mu \mathrm{mol} / \mathrm{mg}$ protein per $\mathrm{h}$ compared to $2.0 \mu \mathrm{mol} / \mathrm{mg}$ protein per $\mathrm{h}$, when $25 \mathrm{mM}$ EGTA was added to the fractions $2 \mathrm{~h}$ before the assay. Similarly, there was also no change in the distribution of $\mathrm{Mg}^{2+}$ ATPase activity on the gradient, when $25 \mathrm{mM}$ EGTA was added to the individual fractions from the gradient prepared in $0.1 \mathrm{mM}$ EGTA immediately before the assay.

In secretory vesicles from adrenal medulla, FCCP (a protonophor) is known to stimulate the $\mathrm{Mg}^{2+}$ ATPase up to $300 \%$ (25). ECCP did not change the enzyme activity in our preparation of secretory vesicles (50\% Percoll, Table I). When $25 \mu \mathrm{g}$ of FCCP was added to $50 \mathrm{\mu g}$ of secretory vesicles in $1.5 \mathrm{ml}$ incubation medium, the enzyme activity in our preparation was $92 \%$ of the control value (2 expts.). Thus, no activation of the enzyme activity was found.

Distribution of $\mathrm{Mg}^{2}+$ ATPase, vasopressin, and acid phosphatase and $\beta$-glucuronidase after further purification of secretory vesicles on a sucrose gradient. Finally, we attempted to remove $\mathrm{Mg}^{2+}$ ATPase and acid phosphatase activities by a further purification of the vesicles, first partially purified on $30 \%$ Percoll gradients containing $0.1 \mathrm{mM}$ EGTA, on sucrose density gradients. For this purpose we applied sucrose gradients used eariier to isolate secretory vesicles from the neurohypophysis $(12)$. 
In Fig. $6 \mathrm{E}$ the relative specific activity of vasopressin (AVP) and $\mathrm{Mg}^{2}+$ ATPase are shown. A difference in the distribution of vasopressin versus $\mathrm{Mg}^{2+}$ ATPase and acid phosphatase (Fig. 6F) is clearly seen.

The specific activity of AVP in the pooled fractions 1-10 recovered from the sucrose gradients was $54 \pm 14 \mu \mathrm{g}$ AVP $x \mathrm{mg}^{-1}$ protein (mean $\left.\pm S D\right)(\mathrm{n}=3)$, and that from the $30 \%$ Percoll gradients $39.3 \pm 16 \mu \mathrm{g}$ AVP $\mathrm{x} \mathrm{mg}^{-1}$ protein $(\mathrm{n}=4)$.

From the results described above it can be concluded that the high specific activity of $\mathrm{Mg}^{2+}$ ATPase present in secretory vesicles isolated on $30 \%$ Percoll gradients containing $0.1 \mathrm{mM}$ EGTA is a contaminant. The low $\mathrm{Mg}^{2+}$ ATPase activity in the vesicles obtained from $50 \%$ Percoll gradients in the presence of $25 \mathrm{mM}$ EGTA reflects a high degree of purity of the vesicles and not an inactivation of the ATPase by the high EGTA concentration used.

The distribution of the acid phosphatase on the sucrose gradient (Fig. 6E, F) suggests a co-purification of $\mathrm{Mg}^{2+}$ ATPase and this enzyme. Therefore, the $\mathrm{Mg}^{2}+$ ATPase found in the secretory vesicles, when prepared on $0.1 \mathrm{mM}$ EGTA/308 Percoll gradients, is present in a different compartment and could be of lysosomal origin.

\section{DISCUSSION}

The determination of kinetic data for $\mathrm{Ca}^{2+}$ uptake and release by secretory vesicles requires that the vesicles must be stable and do not lose intravesicular $\mathrm{Ca}^{2+}$, even if large $\mathrm{Ca}^{2+}$ gradients exist across the vesicle membrane. Also, $\mathrm{Ca}^{2}+$ fluxes should only occur by the mechanism analysed $\left(e . g\right.$. $\mathrm{Na}^{+} / \mathrm{Ca}^{2}+\mathrm{ex}-$ change) and not concomitantly in other ways.

Isolated secretory vesicles, prepared under isotonic conditions on Percoll gradients, are stable and leak little intravesicular hormone (10) or $\mathrm{Ca}^{2+}$ even in case of steep $\mathrm{Ca}^{2}+$ gradients (with EGTA in the incubation medium) (Fig. 1). Since $\mathrm{Ca}^{2}+$ uptake by neurohypophysial secretory vesicles did not exhibit typical saturation with increasing $\mathrm{Ca}^{2}+$ concentrations, a second process, namely $\mathrm{Ca}^{2}+/ \mathrm{Ca}^{2}+$ exchange may actually have contributed to a certain extent to the observed $\mathrm{Na}^{+}$dependent $\mathrm{Ca}^{2+}$ uptake (7). $\mathrm{Ca}^{2}+$ induced $\mathrm{Ca}^{2}+$ release from neurohypophysial secretory vesicles can be demonstrated directly (Fig. 1). This process ( $\mathrm{Ca}^{2}+/ \mathrm{Ca}^{2}+$ exchange) is inhibited by $\mathrm{Mg}^{2}+(\mathrm{Fig} \cdot 2)$. On the other hand, $\mathrm{Na}+/ \mathrm{Ca}^{2}+$ exchange is not affected by $\mathrm{Mg}^{2+}$, neither in secretory vesicles from the neurohypophysis, nor from adrenal medulla $(7,33)$. These facts allowed to measure selectively $\mathrm{Na}^{+}$dependent $\mathrm{Ca}^{2}+$ uptake (in the presence of $\mathrm{Mg}^{2}+$ ). Under these conditions, in a double reciprocal plot of the initial velocity of the $\mathrm{Ca}^{2}+$ uptake as a function of the $\mathrm{Ca}^{2+}$ 
concentration a straight line (saturation was obtained (Fig. 3). This indicated the presence of a carrier with high affinity $\left(\mathrm{K}_{\mathrm{m}}\right.$ approx. $\left.=7 \times 10^{-7} \mathrm{M}\right)$ transporting maximally $1.5 \mathrm{nmol}^{\mathrm{Ca}^{2+}}$ $x \mathrm{mg}^{-1} \times \mathrm{min}^{-1}$ across the vesicular membrane in both NTA and EGTA buffers.

It is not likely that the $\mathrm{Ca}^{2}+/ \mathrm{Na}^{+}$exchange observed occurred to cell membrane vesicles present as impurities. Neither the analysis of gradients composed of $50 \%$ Percoll/25 mM EGTA or 308 Percoll has provided any evidence for cell membrane fragments in this preparation. This is in accordance with earlier findings by Gratzl et al. (10). Særmark et al. (7) also found that $\mathrm{Li}^{+}$has a much smaller effect on $\mathrm{Ca}^{2}+$ uptake than $\mathrm{Na}^{+}$which contrasts to the effect of lithium on the $\mathrm{Na}+/ \mathrm{Ca}^{2+}$ exchange in cell membranes. Finally, it has been reported by Særmark et al. (7.) that the ratio of $\mathrm{Na}^{+} / \mathrm{K}^{+}$ATPase to $\mathrm{Ca}^{2}+/ \mathrm{Mg}^{2}+$ ATPase in neurosecretory vesicles is very different from the ratio in cell membranes from the same terminals. In addition, it was shown (7) that $\mathrm{Ca}^{2+}$ uptake to the secretory vesicle fraction was not inhibited by oligomycin in the presence of ATP. Also, no stimulation by ATP was found.

The apparent concentration of $\mathrm{Na}^{+}(24 \mathrm{mM})$ within the secretory vesicles analyzed is higher than that in the cytoplasm (7). The concentration of free cytoplasmic $\mathrm{Ca}^{2+}$ in several systems varies between 0.1-10 $\mu \mathrm{M}$ (26). The $\mathrm{K}_{\mathrm{M}}$ of the $\mathrm{Na}^{+}$dependent $\mathrm{Ca}^{2+}$ transporter $(0.7 \mu \mathrm{M})$ is obviously of interest in this connection. In the presence of $\mathrm{Mg}^{2+}$ (in concentrations likely to occur in the cytoplasm) $\mathrm{Ca}^{2+} / \mathrm{Ca}^{2+}$ exchange does not take place, but $\mathrm{Ca}^{2+} \mathrm{can}$ be taken up in exchange for $\mathrm{Na}+$ by the secretory vesicles. Whether $\mathrm{Na}^{+}$dependent $\mathrm{Ca}^{2}+$ efflux from secretory vesicles may also occur in stimulated or resting cells is not easy to evaluate. It should be noted, however, that increased intracellular $\mathrm{Na}^{+}$, elicited by specific inhibition of the $\mathrm{Na}^{+} /$ $\mathrm{K}^{+}$ATPase or the $\mathrm{Na}^{+}$ionophore monensin, initiates secretion even in the absence of extracellular $\mathrm{Ca}^{2+}$ (27). This means that the amount of $\mathrm{Ca}^{2}+$ present in secretory vesicles, which can be released by $\mathrm{Na}^{+}$, would be easily sufficient to trigger exocytosis.

Approximately $35 \mathrm{mM} \mathrm{Na}$ are required for half maximal inhibition of $\mathrm{Ca}^{2+}$ uptake by the secretory vesicles. When preloaded with $\mathrm{Ca}^{2+}$ half maximal release of $\mathrm{Ca}^{2+}$ from the vesicles requires roughly the same $\mathrm{Na}^{+}$concentration (7). Direct measurements of $\mathrm{Na}^{+}$uptake by secretory vesicles preloaded with $\mathrm{Ca}^{2}+$ was half maximal at $20 \mathrm{mM}$ (see Results). Since we cannot exclude $\mathrm{Na}^{+} / \mathrm{Na}^{+}$exchange to take place during the experiments, we might have underestimated the affinity of the system for $\mathrm{Na}^{+}$. The data presented here do not allow to determine directly the coupling ratio between the amount of $\mathrm{Na}^{+}$and $\mathrm{Ca}^{2}+$ transported. However, using the data from Fig. 1 an efflux rate of $\mathrm{Ca}^{2+}$ of 8.2 nmol $\times 10 \mathrm{~min}^{-1} \mathrm{x} \mathrm{mg}^{-1}$ protein was found with 130 $\mathrm{mM} \mathrm{NaCl}$ in the extravesicular space. The maximal uptake rate of $\mathrm{Na}^{+}$was $12.9 \mathrm{nmol} \times 10 \mathrm{~min}^{-1} \times \mathrm{mg}^{-1}$ protein under the same con- 
ditions (Fig. 4). This suggests a coupling ratio of 1.6 . We have obtained earlier a coupling ratio of 1.44 from the evaluation of the inhibition of $\mathrm{Ca}^{2}+$ uptake by $\mathrm{Na}^{+}$(7). The precise stoichiometry of the process as well as the demonstration of possible concomitant charge shifts deserve further experimental work.

All data described above indicate that probably $2 \mathrm{Na}^{+}$will be transported across the secretory vesicle membrane in exchange for one $\mathrm{Ca}^{2+}$. It could be predicted, therefore, that release of $\mathrm{Ca}^{2+}$ from the vesicles would result in an increase of the osmolality of the intravesicular fluid due to two moles $\mathrm{Na}^{+}$ taken up per mole of $\mathrm{Ca}^{2+}$ released. Concomitant osmotic uptake of water and vesicle swelling would change the optical density of secretory vesicles suspensions. That this actually happens is shown in Fig. 5. Addition of $130 \mathrm{mM} \mathrm{NaCl}$ to vesicles preloaded with $\mathrm{Ca}^{2}+$ results in a marked reduction of the optical density of the suspension, without leakage of hormone from the vesicles. This effect was specific for $\mathrm{Na}^{+}$since $130 \mathrm{mM} \mathrm{KCl}$ did not cause any changes. Obviously, $\mathrm{Na}^{+}$uptake linked to $\mathrm{Ca}^{2+}$ release can be measured both by the isotope technique described above, as well as the analysis of turbidity measurements. Similar approaches have been made in order to demonstrate coupled transport of metabolites and ions by cell membrane vesiclès (22).

Using a secretory vesicle fraction isolated from the neurohypophysis a low $\mathrm{pH}$ has been measured in the interior and a membrane potential across the vesicle membrane $(28,29)$. Such gradients might provide the driving force for the $\mathrm{Ca}^{2+}$ accumulation and of other components present in these vesicles (e.g. $\mathrm{Na}^{+}$). In analogy to findings with adrenal medullary secretory vesicles (30) the existence of a $\mathrm{Mg}^{2}+$ ATPase has been suggested to provide the energy for such gradients also across neurohypophysial secretory vesicle membranes $(29,31)$. However, we did not detect $\mathrm{Mg}^{2}+$ ATPase activity in the neurohypophysial secretory vesicle fractions recovered from density gradients composed of $50 \%$ Percoll (and $25 \mathrm{mM}$ EGTA in the medium) (Fig. $6 \mathrm{~B})$.

In order to try to resolve the discrepancy on the presence of $\mathrm{Mg}^{2+}$ ATPase in the neurosecretory vesicles we isolated the vesicles according to a procedure described earlier (11) using $30 \%$ Percoll as a gradient material only modified in the way that we added $0.1 \mathrm{mM}$ EGTA to the medium. Actually in such gradients $\mathrm{Mg}^{2+}$ ATPase could not be separated from the secretory vesicle fractions (Fig. 6C, D) and the specific activity of the enzyme in the secretory vesicle fraction recovered amounted to $2.1 \mu \mathrm{mol} / \mathrm{mg} / \mathrm{h}$. This is close to the value reported earlier (24) for secretory vesicle fractions made on sucrose-metrizamide gradients and similar to the activity found in a cell membrane fraction prepared from the same tissue (32). 
Two possibilities were tested to explain the different distribution of the $\mathrm{Mg}^{2+}$ ATPase in the two types of gradients. First, the enzyme could be inactivated by the presence of 25 mM EGTA in the media used during incubation and thus not be detected on the $50 \%$ Percoll gradient; secondly, the enzyme activity could be present in another subcellular structure copurifying with the secretory vesicles on the 30 o percoll gradient. The first possibility could be ruled out by experiments describing the unchanged enzymatic activity of $\mathrm{Mg}^{2}+$ ATPase after prolonged incubation in media containing $25 \mathrm{mM}$ EGTA (see Results). Evidence for the presence of other subcellular structures (e.g. Iysosomes) in the secretory vesicle fractions prepared on the $30 \%$ Percoll gradient is provided by the observation that acid phosphatase, $\beta-$ glucuronidase, as well as $\mathrm{Mg}^{2+}$ ATPase activities, form a second band in the $30 \%$ Percoll gradient fractions containing the highest amounts of vasopressin (Fig, 6C, D). When these fractions were put on a discontinuous sucrose gradient, secretory vesicles could be separated from other structures exhibiting $\mathrm{Mg}^{2+}$ ATPase as well as acid phosphatase activity (Fig. 6E, F).

Thus, with the reservation that some unknown activator is missing in our system, we conclude that there is no $\mathrm{Mg}^{2+}$ ATPase in the neurosecretory vesicles. This conclusion is in accordance with previous work carried out by Vilhardt \& Hope (12) in which, by means of rate zonal centrifugation for a rather long time, the distribution of vasopressin and $\mathrm{Mg}^{2}+$ ATpase was distinctly different.

In the light of the arguments presented, measurements of $\Delta \mathrm{pH}$ as well as membrane potential, sensitive to $\mathrm{Mg}^{2+} \mathrm{ATP}$, carried out with isolated secretory vesicles must be interpreted with caution, since both properties are linked to a proton pumping $\mathrm{Mg}^{2+} \mathrm{ATPase}$ which we have not been able to find in secretory vesicles purified by different methods. It is for future work to establish the mechanisms of forming and maintaining driving forces for the transport processes that we have described in this paper.

ACKNOWLEDGEMENTS. We thank I.Kjeldsen and B.Lynderup for, excellent technical assistance, Professor, Dr. W.Simon, Swiss Federal Institute, zürich for the membranes for the $\mathrm{Ca}^{2+}$ electrode, The Danish Medical Research Council, Fonden til Lægevidenskabens Fremme, Nordisk Insulinfond, P.Carl Petersens Fond and the Deutsche Forschungsgemeinschaft (Gr.681/2-1). We thank the personel at Københavns Eksportslagteri and siagelse Andelsslagteri for help in obtaining the neurohypophyses. 


\section{REFERENCES}

1. Baker, P.F. (1978). The regulation of intracellular calcium in giant oxons of Loligo and Myxicola, in: Scarpa, A. and Carafoli, E. (eds.) Calcium Transport and Cell Function. Ann.N.Y.Acad.Sci. 307, 250-268.

2. Blitz, A.L., Fine, R.E. and Toselli, P.A. (1977). Evidence that coated vesicles isolated from brain are calcium-sequestering organelles resembling sarcoplasmic reticulum. J. Cell Biol. 75, 135-147.

3. Blaustein, M.P., Ratzlaff, R.W., Kendrick, N.C. and Schweitzer, E.S. (1978). Calcium buffering in presynaptic nerve terminals. J. Gen. Physiol. 72, 15-42.

4. Borle, A. (1981). Control, modulation, and regulation of cell calcium. Rev. Physiol. Biochem. Pharmacol. 90, 13-153.

5. Torp-Pedersen, C., Særmark, T., Bundgaard, M. and Thorn, N.A. (1980). ATP-dependent $\mathrm{Ca}^{2}+$ accumulation by microvesicles isolated from bovine neurohypophyses. J. Neurochem. 35 (3), 552-557.

6. Normann, T.C. and Hall, T.A. (1978). Calcium and sulphur in neurosecretory granules and calcium in mitochondria as determined by electron microscope X-ray microanalysis. Cell Tissue Res. 186, 453-463.

7. Særmark, T., Krieger-Brauer, H., Thorn, N.A. and Gratzl, M. (1983). Ca ${ }^{2+}$ uptake to purified secretory vesicles from bovine neurohypophyses. Biochim. Biophys. Acta 727, 239245 .

8. Thorn, N.A., Russel1, J.T. and Vilhardt, H. (1975). Hexosamine, calcium and neurophysin in secretory granules and the role of calcium in hormone release. Ann.N.Y.Acad.Sci. $248,202-217$.

9. Krieger-Brauer, H.J. and Gratzl, M. (1981). Influx of $\mathrm{Ca}^{2+}$ into isolated secretory vesicles from adrenal medulla. Influence of external $\mathrm{K}^{+}$and $\mathrm{Na}^{+}$. FEBS Lett. 133, 244246.

10. Gratzl, M., Torp-Pedersen, C., Dartt, D.A., Treiman, M. and Thorn, N.A. (1980). Isolation and characterization of secretory granules from bovine neurohypophyses. Hoppeseyler's z.Physiol.Chem. 361, 1615-1628.

11. Russell, J.T. (1981). Isolation of purified neurosecretory vesicles from bovine neurohypophyses using isosmolar density gradients. Anal. Biochem. 113, 229-238. 
12. Vilhardt, H. and Hope, D.B. (1974). Adenosine triphosphatase activity in the neural lobe of the bovine pituitary gland. Biochem. J. 143, 181-190.

13. Torp-Pedersen, C.T., Flodgaard, H. and Særmark, T. (1979). Studies on a $\mathrm{Ca}^{2+}$ dependent nuclecside triphosphate pyrophosphohydrolase in rat liver plasma membranes. Biochim. Biophys. Acta 571, 94-104.

14. Sillen, L.G. and Mantell, A.E. (1971). Stability constants of metal-ion complexes. Suppl. No. 1. The Chemical Society London.

15. Bers, D.M. (1982). A simple method for the accurate determination of free $\mathrm{Ca}^{2+}$ in Ca-EGTA solutions. Amer. J. Physiol. 242, C404-C408.

16. Gratzl, M., Dahl, G., Russell, J.R. ard Thorn, N.A. (1977). Fusion of neurohypophysial membranes in vitro. Biochim. Biophys. Acta 470, 45-57.

17. Böhlen, P., Stein, S., Dairman, W. and Udenfriend, S. (1973). Fluorometric assay of proteins in the nanogram range. Arch. Biochem. Biophys. 155, 213-220.

18. Særmark, T. and Vilhardt, H. (1978). Isolation and partial characterization of magnesium ion- and calcium ion-dependent adenosine triphosphatase activity from bovine brain microsomal fraction. Biochem. J. 181, 321-330.

19. Price, R.G. and Dance, N. (1967). The cellular distribution of some rat-kidney glycosidases. Biochem. J. 105, $877-883$.

20. Gianetto, R. and de Duve, C. (1955). Tissue fractionation studies 4 . Comparative study of the binding of acid phosphatase, $\beta$-glucuronidase and cathepsin by rat-liver particles. Biochem. J. 59, 433-438.

21. Særmark, T. and Thorn, N.A. (1982) $\mathrm{Ca}^{2+}-\mathrm{Mg}^{2+}$ ATPase activity in brain coated microvesicles purified on immunosorbents. Cell Calcium 3, 561-581.

22. Lever, J.E. (1980). The use of membrane vesicles in transport studies. Critic. Rev. Biochem. 187-246.

23. van der Meulen, J. and Grinstein, S. (1982). Ca ${ }^{2+-i n d u c e d}$ lysis of platelet secretory granules. J. biol. Chem. 257, 5190-5195.

24. Scherman, D., Nordmann, J.J. and Henry, J.-P. (1982) Existence of an adenosine $5^{\prime}$-triphosphate dependent proton translocase in bovine neurosecretory granule membrane. Biochemistry 21, 687-694. 
25. Johnson, R.G., Beers, M.F. and Scarpa, A. (1982) . $\mathrm{H}^{+}$ATPase of chromaffin granules. J. biol. Chem. 257, 1070410707 .

26. Rasmussen, H. (1981). Calcium and cAMP as synarchic messengers. John Wiley \& Sons, New York.

27. Suchard, S.J., La Hanzio, F.A. Jr., Rubin, R.W. and Pressman, B.C. (1982). Stimulation of catecholamine secretion from cultured chromaffin cells by an ionophore-mediated rise in intracellular sodium. J. Cell Biol. 94, 531-539.

28. Russell, J.T. and Holz, R.W. (1981). Measurement of $\Delta \mathrm{pH}$ and membrane potential in isolated neurosecretory vesicles from bovine neurohypophyses. J. biol. Chem. 256, 5950-5953.

29. Scherman, D. and Nordmann, J.J. (1.982). Internal pH of isolated newly formed and aged neurohypophysial granules. Proc. Nat. Acad. Sci. U.S. 79, 476-479.

30. Njus, D., Knoth, J. and Zallakian, M. (1981) Proton-linked transport in chromaffin granules. In: Sanadi, D.R.: Current Topics in Bioenergetics, vol. 1l, p. 107-147, Academic Press, New York.

31. Brownstein, M.J. (1982). Post-translational processing of neuropeptide precursors. Trends in neurosciences. Sept. 1982 , p. 318-320.

32. Conigrave, A.D., Treiman, M., Sarmark, T. and Thorn, N.A. (1981). Stimulation by calmodulin of $\mathrm{Ca}^{2+}$ uptake and $\left(\mathrm{Ca}^{2+}-\mathrm{Mg}^{2+}\right.$ ) ATPase activity in membrane fractions from ox neurohypophyses. Cel1 Calcium 2, 125-136.

33. Krieger-Brauer, H.J. and Gratzl, M. (1982). Uptake of $\mathrm{Ca}^{2+}$ by isolated secretory vesicles from adrenal medulla. Biochim. Biophys. Acta 631, 61-70.

received $24: 1: 83$

revised version received and accepted $25: 3: 83$ 